\title{
The physical carrying capacity of mangrove ecotourism in Blanakan, Subang Regency, West Java, Indonesia
}

\author{
Ufairah Hartanti ${ }^{1, *}$, Mufti Petala Patria ${ }^{2}$, and Suyud Warno Utomo ${ }^{3}$ \\ ${ }^{1}$ School of Environmental Science, Universitas Indonesia, Indonesia \\ ${ }^{2}$ Department of Biology, Faculty of Mathematics and Natural Science, Universitas Indonesia, \\ Indonesia \\ ${ }^{3}$ Department of Environmental Health, Universitas Indonesia, Indonesia
}

\begin{abstract}
Blanakan mangrove forest is a form of biodiversity wealth owned by Indonesia. This forest has several tourism objects both in terms of nature and culture. Natural attraction such as mangrove diversity, crocodile breeding sites, and mangrove zonation. Cultural attraction such as Nadran ceremonies (sea party) and Sisingaan. Based on tourist visit data, the number of tourists has increase from year to year. However, it is feared to cause environmental damage and inconvenience for visitors. Therefore, the physical carrying capacity as the maximum number of tourists in tourist area needs to be taken into account. This research aims to analyze the physical carrying capacity of Blanakan mangrove ecotourism. The method of the research is quantitative method. This research analyzed by physical carrying capacity method. The result is the physical carrying capacity is 77.000 visitors/day. Relative carrying capacity is 2.750 visitors/day and effective carrying capacity is 825 visitors/day. While, the average tourist visit rate per day is 57 people. This research that the carrying capacity of the Blanakan mangrove ecotourism has not been exceeded.
\end{abstract}

\section{Introduction}

Indonesia has wealth of nature in the form of high biodiversity (Flora and Fauna). The example of biodiversity is mangrove ecosystem. The mangroves plant in Indonesia is divided into 14 families, including Apocynaceae, Bignoniceae, Combretaceae, Euphorbiaceae, Leguminoseae, Meliaceae, Myrtaceae, Palmae, Rhizophoraceae, Rubiaceae, Rutaceae, Sonnerataceae, and Avicenniuceae [1]. Mangroves is the richest carbon value around 1023 per $\mathrm{Mg} \mathrm{C}$ per hectare [2]. Mangroves have many benefits in terms of physical, economic, social, and tourism [3]. The physical function of the mangrove are keep stable the coastline, protect the river cliffs from the erosion or abrasion, holding or absorbing strong winds from the sea to land [4,5]. The social-economic funtions of the

\footnotetext{
${ }^{*}$ Corresponding author: u.hartanti95@gmail.com
} 
Mangroves are source of foreign exchange, both for society industry, and the country [6,7]. Because of the mangrove benefits, it can be vulnerable to occur the environment degradation [8]. Therefore, it takes the concept of ecotourism to reduce environment damage [9].

The concept of ecotourism originated from concerns about environmental damage caused by mass tourism activities [10]. Ecotourism is a tourism activity to understand nature and socio-culture which provide economic opportunities for local society without destroying the natural balance functions [11]. Ecotourism is a form of sustainable development about tourism related to efforts keep remain sustain the nature, social, and culture resources so that it can be enjoyed not only for present generation but also the next generation [12]. Sustainable tourism focus on the principal of local participation, participation of stake holder, local ownership, sustainable use of resources, attention to the carrying capacity of tourist area, accommodating community goals, monitoring and evaluation, accountability, training and promosion [13]. There are five guidelines that must be considered in ecotourism activities such as education, advocacy, monitoring, community involvement and conservation [14].

Blanakan mangrove forest has an area of 131.37 hectares [15]. Mangrove forest Blanakan has great potential to be developed as tourist attraction. Blanakan mangrove forest have tourists attractions such as flora and fauna diversity associated with mangrove ecosystems, the existence of mangrove zoning, there are locations of estuarine crocodile breeding, Nadran (sea party) and Sisingaan ceremonies [16]. The great potential tourist attraction in mangrove forest Blanakan can be increase the interest of tourist visits. It can be seen from the increasing number of visitors from year to year. The number of tourists is feared to pose a threat to biodiversity. The increasing number of visitors allows inconvenience for visitors. Convenience is an important factor for visitors who are in a location of tourism area. Therefore, a concept of ecotourism which takes into account the concept of carrying capacity of the region is needed.

By the calculate carrying capacity in tourism area, the managers can determine the maximum number of visitors so that they are comfortable traveling in Blanakan mangrove forest. This research aims to analyze the physical carrying capacity of Blanakan mangrove ecotourism. The benefits of this research are provide an alternative in determining the policy of mangrove ecotourism development which still attention to the condition of ecology, social, and economy of the surrounding society; provide insight to the society about the benefits of mangrove forest for the socio-economic life of the society; provide information for ecotourism's manager to developed of sustainable ecotourism management.

\section{Methods}

Primarily this research takes a quantitative approach. The method of this research used quantitative methods. The methods of the data collection is survey with questionnaire. The technique use for sampling is simple random sampling. This research use biological aspects data and the number of visitors. Biological aspects data such as list of biota (vegetation and animal data). Data will be analyze with ecological carrying capacity analysis [17].

Carrying capacity is the total amount of productive and assimilative capacity of particular ecosystem concerning the area usefull [18]. The concept of carrying capacity has widely used as guide for managing ecotourism regularly and systematically to reduce the smallest impact [19]. The Physical carrying capacity in this research defined as the 
maximum number of tourist who use the tourist area without affecting the functions of ecological balance and it can still meet the demand of visitors [20]. Carrying capacity generally consists of three components [21]. There are physical, ecological, socialeconomic carrying capacity [22].

Calculation of regional carrying capacity in this research $[23,24]$, are:

1. Physical carrying capacity, which is the maximum number of visitors who can fill a space determined in certain time.

Where:

$$
\mathrm{PCC}=\mathrm{A} \times \frac{\mathrm{V}}{\mathrm{a}} \times \mathrm{Rf}
$$

PCC : Physical carrying capacity

A : : Area available for public use

$\mathrm{V} / \mathrm{a} \quad$ : Area needed for one visitor per $\mathrm{m}^{2}$

$\mathrm{RF} \quad:$ The rotation factor

2. Real carrying capacity (RCC), which is the maximum number of visitors allowed for an immediate location after correction factors are derived from special features of a place have been treated with PCC.

$$
\mathrm{RCC}=\operatorname{PCC} \times \frac{100-C f 1}{100} \times \frac{100-C f 2}{100} x \ldots \ldots . \frac{100-C f n}{100}
$$

3. Effective carrying capacity (ECC), which is the maximum number of visitors per person that can be accommodate place with availability of capacity management.

$$
\mathrm{ECC}=\frac{(\text { Infrastructure capacity } \mathrm{xMC})}{\mathrm{RCC}} \times 100 \%
$$

Where:

ECC : Effective or permitted carrying capacity

MC : Management capacity based on number of staff and budget

RCC : Actual carrying capacity

\section{Result and discussion}

\subsection{Tourism objects potential of Blanakan mangrove forest}

Blanakan mangrove forests have three types of potential tourism objects, namely the potential of natural attractions, cultural attractions, and artificial tourism objects. The potential of Blanakan mangrove forest natural attractions such as the beauty of mangrove vegetation that has a unique root system, the diversity of animals associated with mangroves, natural scenery in the form of beaches, and estuaries that can be traced by boat. The potential of cultural tourism objects are the sea party ceremony ("Nadran"), the "sisingaan" art, and the activities of mangrove utilization by local residents. Artificial tourism potential namely crocodile breeding, typical Blanakan culinary offerings, camp sites and fish auction sites.

The example of the potential of Blanakan mangrove forest natural tourism objects is flora and fauna diversity associated with mangrove trees. Plants in the Blanakan mangrove forest area are dominated by four types, namely Avicennia marina, Sonneratia sp., Rhizopora sp., and Bruguiera sp. Avicennia marina and Sonneratia sp. are plants that grow 
more in areas adjacent to the sea. Avicennia marina is a pioneer plant that has the ability to grow and develop in tidal areas. Avicennia marina is able to survive in tidal areas because it has a root of breath that can help the sediment binding and accelerate the process of soil formation. Rhizopora sp. is a type of mangrove which is found in areas that lead to land. Bruguiera sp. usually grows in the middle part of mangrove vegetation which is towards land (behind Avicennia zone).

Table 1. Important value index (IVI) of mangrove species in Blanakan mangrove ecotourism.

\begin{tabular}{|c|c|c|}
\hline Growth rate & Type of mangrove & IVI (\%) \\
\hline Tree & Avicennia marina & 258,65 \\
\hline & Rhizopora sp. & 30,88 \\
\hline & Sonneratia $s p$. & 10,47 \\
\hline & Total & 300 \\
\hline Stake & Avicennia marina & 210,76 \\
\hline & Rhizopora $s p$. & 80,12 \\
\hline & Sonneratia $s p$. & 9,12 \\
\hline Sapling tree & Total & 300 \\
\hline & Avicennia $s p$. & 162,51 \\
\hline & Rhizopora $s p$. & 82,76 \\
\hline & Sonneratia $s p$. & 48,82 \\
\hline & Bruguiera $s p$. & 5,91 \\
\hline & Total & 300 \\
\hline
\end{tabular}

Based on table 1, it can be concluded that the highest important value index of mangrove species in Blanakan mangrove ecotourism is Avicennia marina. Important value index for tree growth rates is $258,65 \%$. Important value index for stake is $210,76 \%$. Important value index for sapling tree is $162,51 \%$. It shows that dominated species and the largest supplier of nutrients to sea waters in Blanakan mangrove ecotourism is Avicennia marina.

Fauna in Blanakan mangrove forest are crabs, mud lobsters (Thalassina sp.), Spider species (Argipe sp., Nephila sp., Cryptophora sp.), Monitor lizards (Varanus sp.), Tree snakes (Crysopelea sp.), air caterpillar (Cerberus sp.), mammal beaver (Lurogale sp.). In addition to these fauna there are species of migratory birds namely Blekok (Ardeola speciose) and Curek (Calidris ruficollis), a type of water bird that lives on the beach namely Belibis (Dendrocyna javanica) and Kuntul (Egretta intermeding). 


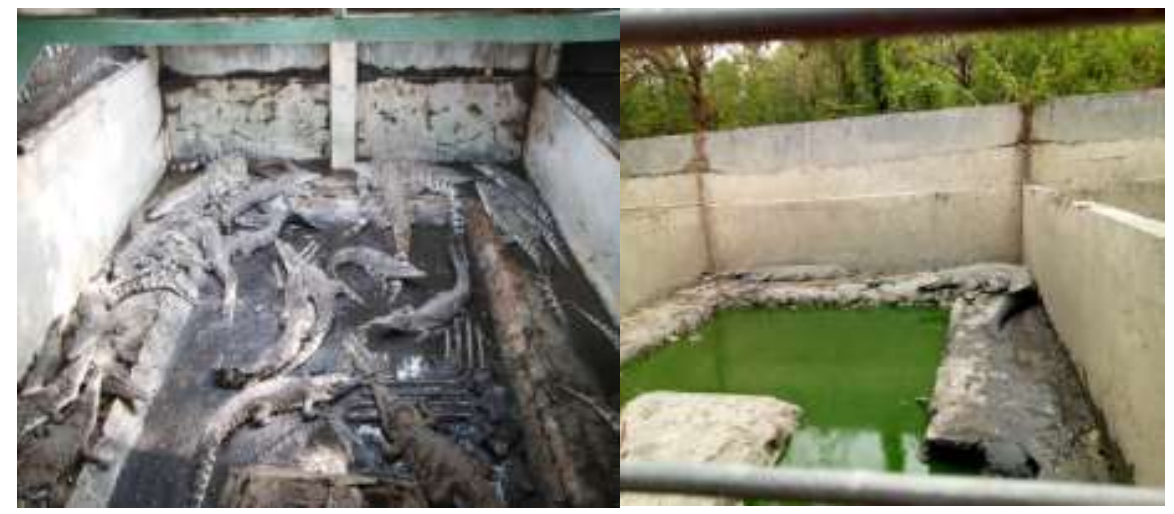

Fig. 1. Location of crocodile breeding in Blanakan Mangrove Forest.

The most dominating fauna in the Blanakan mangrove forest is the estuarine crocodile (Crocodilus porosus). This happens because the Blanakan mangrove forest is a crocodile breeding location (Fig.1) that has been built since 1989. This crocodile breeding has become a mainstay tourist attraction since long ago. Blanakan crocodile breeding has 30 ponds with a size of 200 square meters.

Other potential tourism objects of Blanakan mangrove forest are potential cultural tourism objects such as "Sisingaan" and "Nadran". Art "Sisingaan" is one of the regional arts as a symbol of colonial power. The power of the invaders is manifested in the form of a lion. Lions are ridden by a child as a symbol of harassment against invaders. This means that the people of Subang are not afraid of invading the invaders. This traditional art is held every April 5 along with the anniversary of Subang Regency. Whereas "Nadran" is a traditional ceremony commonly carried out by coastal communities in Blanakan. Nadran is a tradition of acculturation results of Islamic and Hindu culture that has been handed down for hundreds of years from generation to generation. The "Nadran" ceremony is a symbol of gratitude to God for the abundant fish catch and hopes for increased yields in the coming year and asks for safety in seeking sustenance in the sea.

\subsection{Carrying capacity of Blanakan mangrove ecotourism}

Physical carrying capacity (PCC) for mangrove ecotourism in The Blanakan is calculated based on the specified criteria, such as the effective area, visitor variables, and average time for visitors to spent their time in the Blanakan mangrove ecotourism. The effective area used for tourism activity is 5 hectare. Other criteria is visitor variables which is every person in general requires need a horizontal space about 1 meter square to be able to move freely. Opening time of tourist attraction between 09.00 A.M until 05.00 P.M. It means, Blanakan mangrove ecotourism open for 8 hours, but average time for visitors to spent the tourism activity about 5,2 hours. So, the result of PCC calculation is 77.000 visitors per day.

Carrying capacity is not only calculated based on physical capacity but also calculated based on relative carrying capacity (RCC) and effective carrying capacity (ECC). In determining the relative carrying capacity, there are several correction factors which can be used as a limiting factor for visits. Such as, physical environmental factors (weather 
conditions), psychological factors related to comfort and distress utilization area, and management factors. So, the result of RCC calculation is 2,750 visitors per day.

Carrying capacity is allowed or effective (ECC) calculated based on management capacity, location opening times, and travel time to enter tourism location. The result of $\mathrm{ECC}$ is $30 \%$. So, the ECC value of Blanakan mangrove ecotourism area is $30 \%$ of RCC (2.750) is 825 visitors per day.

The result of carrying capacity in Blanakan mangrove ecotourism for physical carrying capacity is 77.000 visitors per day. Relative carrying capacity is 2.750 visitors per day and effective carrying capacity is 825 visitors per day. If this results compared to Wonorejo mangrove eotourism for physical carrying capacity is about 87.990 visitors per day [25]. Relative carrying capacity is about 3.288 visitors per day and effective carrying capacity is 987 visitors per day [25]. The result of carrying capacity in Blanakan is lower than Wonorejo because effective area used for tourism activity and average time for visiotrs to spent the tourism activity in Blanakan tourism is lower than Wonorejo. In addition, differences in correction factors related to the physical condition of regions that different between Blanakan and Wonorejo such as rainfall, water quality, seasonal flooding and management capacities.

\section{Conclusion}

The model of mangrove ecotourism development is expected to pay attention to the ecological indicator. It marked will not exceed the carrying capacity of the area. So, the environmental damage can be reduced.

\section{Acknowledgements}

This research is financially supported by faculty of mathematics and natural sciences, Department of biology, Universitas Terbuka to Dr. Suyud Warno Utomo. The project was completed under the coordination of Perhutani III Public Corporation Purwakarta, the village cooperative unit "Fajar Sidiq" and the Subang Agrarian and Spatial Planning Office.

\section{References}

1. Widyastuti, Ani, Edy Yani, Ery Kolya Nasution, Rochmatino. Biodiv. 19, 246-252 (2018)

2. N. Mukherjee, Sutherland, Dicks, Huge, Koedam, and Dahdouh-Guebas. PLoS One. 9, 9 (2014)

3. D. Daniel C., Boone Kauffman, Murdiyarso, Kurniato, Stidham and Kanninen. Nature Geoscience 4, 293 (2011)

4. Natalia D, Arisoesilaningsih, Hairiah K. J Agric Sci. 39, 74-82 (2017)

5. S. Almeida A., M. Luis Junior, G. Benard S. Forest 5, 1967-1981 (2014)

6. Ardhana, I Putu Gede, I M.G.S. Rimbawan, Pujo Nur Cahyo, Yuyun Fitriani, Siska Rohani. Biodiv. 19, 918-926 (2018)

7. Polidoro, Carpenter, L. Collins. PLoS ONE 5, 4 (2010)

8. Feller, Lovelock, U. Berger, McKee, Joye, and M.C. Ball. Annu. Rev. Mar. Sci. 2, 395-417 (2010)

9. S. Ashok, Tewari, Behera, and Majumdar. Touri. Manage. Persp. 21, 24-41 (2017)

10. Deng, J., Bender, M., \& Selin, S. J. Ecotourism 10, 77-85 (2011) 
11. Ghorbani, Raufirad, Rafiaani, and Azadi. Touri. Manage. Persp., 16, 290 (2015)

12. Zambrano, Eben, and W.H. J. Ecotourism 9, 62-83 (2011)

13. Youdelis, Megan. Geoforum 50, 161-171 (2013)

14. Li Wenjun. Touri. Manage. 25, 559 (2004)

15. Indonesian forest companies "Tegal Tangkil Forest area", annual report book for inventory data "Tegal Tangkil Forest area" (Indonesian forest companies, Jakarta, 2017)

16. Armono, Rosyid, and N.I. Nuzula. IOP Conf. Ser. : Earth Environ. Sci. 79, 12.004 (2017)

17. Saveriades, A., Touri. Manage. 21, 147-156 (2000)

18. Carr, M.H. Environ. Conserv. 27, 106-109 (2000)

19. Sharma. Global J. Environ. Sci. Manage. 2, 187-196 (2016)

20. Nghi, Lan N.T, Thai M.D., and Thanh D.X.. J. Sci. Earth Sci. 23, 80 (2007)

21. Bhattacharya, A.K., Banerjee, S. The Indian Forester 3, 330 (2003)

22. Sharma, R., Bhattacharya, A.K. J. Environ. Sci. 3, 77-85 (2014)

23. Rios-Jara, Galvan-Villa, Rodriguez, Lopez-Uriate, and Munos-Fernandez. Environ. Manage. 52, 335-347 (2013)

24. Cifuentes MA. Determination carrying capacity of tourism in protected area (CTIE Papers, Costa Rica, 1992)

25. Murtini, Kuspriyanto, and Kurniawati. J. Phys.: Conf. Ser. 953, 12.174 (2017) 